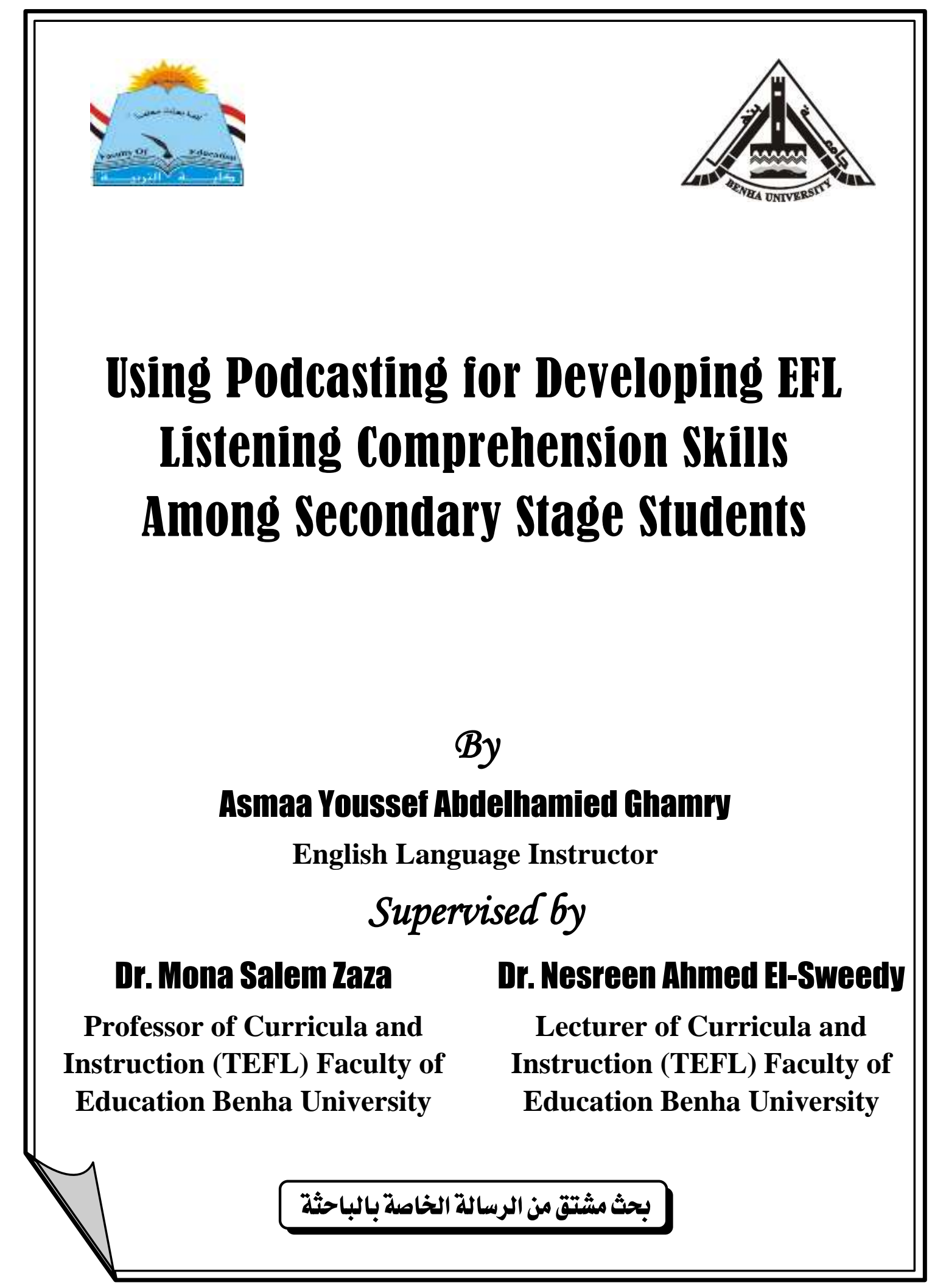




\section{Using Podcasting for Developing FFL Listening Comprehension Skills Among Secondary Stage Students}

By

Asmaa Youssef Ahdelhamied Ghamry

English Language Instructor

Supervised by

\begin{tabular}{cc} 
Dr. Mona Salem Zaza & Dr. Nesreen Ahmed El-Sweedy \\
Professor of Curricula and Instruction & Lecturer of Curricula and Instruction \\
(TEFL) Faculty of Education & (TEFL) Faculty of Education \\
Benha University & Benha University \\
\hline \hline
\end{tabular}

Ahstract

The present study aimed at developing EFL listening comprehension skills among first year secondary stage students using podcasting. The participants of the study consisted of first year secondary stage students in Alsadat Secondary School for Girls, in Alzaqaziq $(\mathrm{N}=36)$. The study followed the one-group pre-post test design. A Pre-post listening comprehension skills test was administered to a group of first year secondary stage students. The students were taught using podcasting to develop their listening comprehension skills. Then, the test was administered again. T-test was used to compare the mean scores of prepost test of the study participants. Results of the study revealed that the participants' EFL listening comprehension skills improved significantly as a result of using podcasting. Therefore, it can be concluded that using podcasting is effective in developing EFL first year secondary stage students' listening comprehension skills.

Keywords: EFL listening comprehension skills, Podcasting.

\section{1}




\section{Introduction}

The importance of listening in language learning can't be underestimated. Through receiving input, we understand linguistic information in order to produce language. According to Brown (2000) students do more listening than speaking in classrooms. Listening is important for some reasons for foreign language learners. First, listening is an important precondition for oral communication to happen. Second, it has an influence on developing reading and writing. Third, it is an important factor in academic success, since students comprehend teachers or lectures through listening (ELkoumy, 2002).

Besides, listening has a very effective role in the process of learning and language acquisition, "for it is the key to improve speaking, reading and writing; it is used at least three times as much as speaking, and four to five times as much as reading and writing" (Grognet and Duzer, 2002, p.1). For young pupils, listening and trying to understand the spoken language is a powerful beginning for language acquisition process. To accelerate this process, pupils need to hear a lot of meaningful language input (Bozorgian and Pillay, 2013). In addition, Rost (2011) and Vandergrift (1999) asserted that listening is highly used and integrative language skill, as it is used in conjunction with the other language skills: speaking, reading and writing. It is extremely important in the process of acquiring a second language. Moreover, Hemmati, Gholamrezapour and Hessamy (2015) added that if a learner can listen effectively, success of the rest of the skills and mastering language learning will follow naturally.

In order to comprehend a spoken message, four main types of knowledge may be drawn on: phonological (the sound system); syntactic (how words are put together); semantic (word and propositional knowledge); and pragmatic (the meaning of utterances in particular situations) (Flowerdew and Miller, 2005).

Listening comprehension is a mental process that is very complicated. In which listeners have little chance to read the message or 
the words again. Dealing with sound input is totally different from dealing with written language (Liu, 2009). Thus, all language learners face difficulties when listening; as listening comprehension still remains one of the least understood processes (Goh, 2000; Hamouda, 2013).

Hamouda (2013), Goh (2000) and underwood (1989) identified some problems which encounter learners while listening:

- Lack of control over the speed at which speakers speak, or the speed rate of speech is too fast to comprehend.

- The inability to get things repeated.

- The listeners limited vocabulary which hinders listeners to understand the message.

- Failure to recognize the 'signals' which show that the speaker is moving from one point to another e.g. (secondly,......or, then,......).

- Problems of interpretation since learners who miss experience with different meanings of words and non-verbal cues, facial expression, nods, gestures, tone, etc. cannot understand the meaning well.

- Unclear pronunciation of some speakers, different accents and dialects, especially the difference between British English and American English.

- Failure to use and apply strategies while listening.

To overcome listening comprehension problems mentioned above we should understand that there are two types of cognitive processing in listening: bottom-up and top-down processing. Top-down processing refers to using schemata (background knowledge and overall understanding students already possess) to make sense of the information, construct meaning and interpret the message (Duzer, 1997 and Vandergrift, 2004). On the other hand, bottom-up processing refers to understanding the meaning of the message through incoming language data, from sounds, to words, to grammatical relationships, to meaning. 
Stress, rhythm, and intonation also play a role in bottom-up processing (Duzer, 1997). Rezaei and Hashim (2013) added that bottom up processing includes continuous attention to input details, whereas top down processing demands from a listener to predict and make inferences based on the incoming data. Moreover, in bottom up processing "the learner may decode sounds from the simplest form-a phoneme-to an oral discourse. It can be said that this mode goes through a phonetic level, then syntactic level, followed by a semantic level, and finally literal understanding" (Cabezas, 2015, p.40). Richard (2008) concluded that, "whereas bottom-up processing goes from language to meaning, topdown processing goes from meaning to language" (p.7).

To teach listening skills, Grognet and Duzer (2002) said that activating background knowledge and vocabulary are essential factors. In prelistening activities teachers should review the information the learners already know about a topic. During this stage learners recall from longterm memory all what they know about the topic. Then, the listeners are ready to do the listening task itself in which they focus on getting information. Post-listening activities help listeners to make sure if they were successful or failed in the listening task, to increase their background knowledge and to integrate with other language skills. Grognet and Duzer (2002) added that there are guidelines for teaching listening lessons. First of all, materials should be authentic. Second, "the language should reflect real discourse, including hesitations, rephrasing, and a variety of accents"(p.3). Third, level of difficulty of the task can be detected based on the level of listeners. At the beginning level, listeners may listen and choose the correct items. At an intermediate level, the listeners may listen to a set of instructions, then carry out them. At an advanced level, they might listen to a meeting and write a summary for what tasks the manager gave to employees. Fourth, focus should be on developing listening strategies which increase the opportunities for successful listening e.g., predicting, asking for clarification, using nonverbal cues. 
Nowadays, the world is changing rapidly with the advent of new technologies which provide teachers and learners with many potentials. Teachers should make use of the new technological gadgets and applications. Podcasting is an innovative technology for broadcasting audio files and programs on the internet has been introduced in 2005 and since then there have appeared rapid advances (Selingo, 2006). Podcasting which was originally a tool for conveying information, news, and entertainment, soon, was detected by educators who properly noticed the potential it can have for teaching and learning (Adams, 2006).

The word podcast was first invented in 2004 by mixing the words ipod and broadcast together (Kavaliauskienè and Anusiené, 2009). In 2005, editors of New Oxford American Dictionary announced this word as the word of the year. Many researchers defined a podcast as a series of audio files (sometimes video) that can be downloaded automatically through subscription to an RSS (Really Simple Syndication) feed (Cebeci and Tekdal, 2006; Selingo, 2006). Al Qasim and Al Faddda (2013) added that podcasts are composed in general of audio files which are easier to create than video podcasts

Hasan and Hoon (2012) and Vogt, Schaffner, Ribar and Chaves (2010) mentioned that podcasting allows learners to access authentic materials and develop their language skills, gives opportunities to develop their vocabulary and grammatical structure. It is also important as a source for learning many aspects such as culture, history and policies. In addition, Ashraf, Noroozi, and Salami, (2011), Hasan and Hoon, (2012); Sanjana, (2014); and Forbes and Khoo (2015) found out that podcasts motivate learners to learning English, develop their language skills, especially listening, and provide a lot of chances for learning and sharing ideas with one another.

In addition, podcasting is an opportunity to compensate for short period of lectures; podcasts allowed teachers to duplicate, extend and improve lectures outside classrooms (Cebeci \& Tekdal, 2006 \& Hew, 
2009). Then, students attend the lecture using the podcast as a backup for asking about complex topics. O'Bannon, Lubke, Beard and Britt (2011) added that podcasts help in preparing the learner for new information. One of the most important benefits of podcasts to adult learners who don't find time for face-to-face learning is distance education; as podcasts allow them to use interviews and discussions with internal and external experts (Roy and Roy, 2007).

Swetha (2013) mentioned four different file forms of podcasts: audio podcasts, video podcasts, enhanced podcasts and podcast novels. Audio podcasts are the most common and widely used type. They usually take the form of an MP3 file format. AAC and WMA are rare file format of this type. Depending on the length, the audio file does not usually exceed $10 \mathrm{Mb}$, which makes it one positive side of this type.

Creating a podcast is a very easy and simple process. Watson (2005); Lucking; Purcell and Christman (2006); Roy and Roy (2007) and Buffington (2008), stated that there are specific steps for creating a podcast as follows: (1) a microphone is attached to a computer. The presence of microphone is an essential element in the creation of a podcast. (2) sound editing software is installed (its freely available online eg; Audacity or it can be found at http:// www.mp3mymp3.com). It is a program which must be installed to manage the recording and the edition. (3) the content ( conversation, song, or anything else) is converted to MP3 format for audio and MP4 for video, then edited. (4) the recorded file is uploaded to a podcasting website that makes it available for the internet users to listen to it, watch it or download it.

According to Fox (2008), teaching English using podcasting can be in different forms. Students can listen for pleasure. They can also listen with a prepared teacher glossary to help to make the show accessible to lower levels. Students may listen to a short chunk. Most of the podcasts are divided into more or less independent sections which can be listened to. This makes the task more manageable for lower levels. Besides, they may listen with a transcript (prepared by the teacher). This is a 
controversial issue. Many teachers see a transcript as an obstacle to learning and preparing transcripts is a time consuming job which most podcasters do not do. A chunk as dictation practice is a very useful exercise which many teachers reject as old-fashioned. A potentially more rewarding reason is that it could be used to heighten awareness of authentic speech and how it differs from formal written language. Such chunks could be placed in text manipulation programs for further practice. The last form is listening to a slowed down version: windows media player now include functionality to slow down the recording and some students may find this helpful. Audacity also does this.

Abeddaim (2013) suggested in his study that using podcasting can help students develop their listening comprehension better than the use of the traditional method. Gul Ince (2015) mentiond that the findings of his study showed that the learners generally had positive opinions about this technology. Most of them found it easy to use, effective in language learning and enjoyable at the same time. Moreover, Hassen (2016) added that podcasts can help EFL learners to enhance their listening comprehension and teachers consider it an effective tool that facilitates teaching listening courses.

\section{Context of the Problem}

Listening is usually a neglected skill; it doesn't attract teachers' attention and the time devoted for teaching it in the classrooms is allocated to teaching other skills, especially writing and reading (Al-Harriree, 2004).

Needless to mention that most of the English language teachers concentrate on teaching writing and reading skills, and pay less attention to listening and speaking. Teachers attribute this to the nature of the examination system which concentrates mainly on the reading and writing skills (Abdel Khalk, 2011).

Based on the researcher's teaching experience, it can be said that secondary school students lack EFL listening comprehension skills and 
these listening skills do not receive the required interest. Teachers ignore teaching listening skills, because they concentrate on the basic information that can help students to pass their written exams. In addition, examining 15 exams from different governorates prepared for secondary stage students, it was found that there is no section devoted to test listening comprehension skills.

To make sure of the study problem, a pilot study was conducted on 30 first year secondary stage students at Elsadat Secondary School for Girls, in Alsharqeya Governorate during the second term of the academic year 2014/2015. An EFL listening comprehension test prepared by the researcher was applied. The results of the test revealed the poor level of the students' EFL listening comprehension skills.

This lack of EFL listening skills was also pointed out by different studies (Seif El Nasr, 2003, Al-Harriree,2004, Abdel-Hafez, 2006, Radwan, 2010, Selim, 2011). These studies stated that the main focus in teaching English is mostly on grammatical aspects and written work rather than on listening skills. So, listening skills are still neglected in our English classes. Thus, there is a need for an effective way for developing listening comprehension skills for secondary stage students.

\section{Statement of the Problem}

The problem of the present study lies in the lack of EFL listening comprehension skills among first year seconday school students, at Alsadat Secondary School for Girls, at Alsharqeya Governorate. This study is an attempt to investigate the effectiveness of using podcasting for developing EFL listening comprehension skills among first-year secondary school students.

\section{Questions of the Study}

This study attempted to answer the following questions;

1- What are the EFL listening comprehension skills required for first year secondary school students? 
2- How can podcasting be used for developing EFL listening comprehension skills among first year secondary stage students?

3- What is the effect of using podcasting on developing EFL listening comprehension skills among first-year secondary school students?

\section{Aim of the Study}

The study aimed at developing some EFL listening comprehension skills for first year secondary stage students using podcasting.

\section{Delimitations of the Study}

This study was delimited to:

1- A sample of first year secondary school students at Alsadat Secondary School for Girls in Alzaqaziq, Alsharqeya Governorate.

2- Some EFL listening comprehension skills required for first-year secondary school students.

\section{Research Methodology}

This study utilized the quasi-experimental design known as the one-group pre-post test design.

\section{Participants of the Study}

The participants of the present study consisted of first year secondary stage students $(n=36)$ at Elsadat Secondary School for Girls, in Alzaqaziq, Alsharqeya Governorate, during the academic year 2017/2018.

\section{Instruments and Materials of the Study}

\section{a) checklist of EFL listening comprehension skills.}

Based on the review of literature and studies related to listening comprehension, a preliminary list of listening comprehension skills was prepared. The list was submitted to a jury of ten staff-members in TEFL and five English supervisors to verify its validity. The jury members were asked to determine the appropriateness of 28 skills to the first year secondary stage 
students. Changes and modifications concerning the skills were considered. Based on the jury's feedback, thirteen skills were agreed upon.

\section{b) pre-post EFL listening comprehension skills pre-post test.}

The EFL listening comprehension skills test was designed to measure the 13 sub-skills assigned as very important by the jury members. Two questions were assigned to measure each skill. Five listening passages were selected. The test was submitted to jury members in Curricula and Methods of Teaching English $(n=15)$. They were asked to indicate the suitability of the test content for the first year secondary stage students and the clarity of the instructions for each part of the test. They indicated the suitability of the test items to assess the skills intended.

For estimating the reliability of the EFL listening comprehension test, Alpha Cronbach coefficient and test-retest method were used. The test was administered to a group of $1^{\text {st }}$ year secondary school students at Alsadat Secondary School for Girls, Alzaqaziq, Alsharqeya Governorate (other than the experimental group who received the treatment) $(\mathrm{N}=37$ ) during the second semester of the academic year 2017/2018. Then, it was administered to the same group again after two weeks. The Pearson correlation between the two administrations was (.997) which is significant at the 0.01 level. Alpha Cronbach coefficient was (.805) which shows that the test is reliable. This means that the EFL listening comprehension pre-post test is reliable. The test was administered to the participants as pre-post test.

\section{The Intervention}

A teacher's guide was designed to explain in details how podcasting can be used for developing EFL listening comprehension skills. Ten sessions were prepared. At the beginning of each session, the teacher showed students some pictures for story, then started asking some brain storming questions about the story, the character, and the events. After that students listened to the audio many times and in each time they listened and did some activities. The teacher asked them to 
retell the story in their own words using a microphone and this was recorded using audacity program. Then, the audio was uploaded to Edmodo site where students could listen again and again and give likes and comments to their classmates and ask the teacher any question if they misunderstood any point.

\section{Results of the Study}

Data were statistically treated using Statistical Package for the Social Science (SPSS) program (version 18). Table (1) and (2) show the results of the study.

Table 1: Findings of t-test and $\square 2$ between the EFL listening comprehension pre and post test

\begin{tabular}{|c|c|c|c|c|c|c|c|c|}
\hline Skill & $\mathbf{N}$ & Application & Mean & S.D & $\begin{array}{c}\text { t- } \\
\text { Value }\end{array}$ & D.F & Sig. & $\square \mathbf{2}$ \\
\hline \hline $\begin{array}{c}\text { EFL listening } \\
\text { comprehension } \\
\text { skills }\end{array}$ & 36 & Pre & 9.9444 & 3.40541 & & & & \\
\cline { 3 - 8 } & Post & 28.3611 & 4.16209 & 28.647 & 35 & .001 & 0.95 \\
\hline
\end{tabular}

Table 2: Findings of t-test and $\square 2$ between the EFL listening comprehension pre-test application and the EFL listening comprehension post-test application in each main skill

\begin{tabular}{|c|c|c|c|c|c|c|c|c|}
\hline $\begin{array}{l}\text { Main } \\
\text { Skills } \\
\end{array}$ & $\mathbf{N}$ & Application & Mean & S.D & $\begin{array}{c}\mathrm{t}- \\
\text { Value } \\
\end{array}$ & D.F & Sig. & $\square 2$ \\
\hline \multirow{2}{*}{ Literal } & \multirow{2}{*}{36} & Pre & 4.8333 & 2.04939 & \multirow{2}{*}{17.930} & \multirow{2}{*}{35} & \multirow{2}{*}{.001} & \multirow{2}{*}{0.90} \\
\hline & & Post & 11.5278 & 1.88961 & & & & \\
\hline \multirow{2}{*}{ Inferential } & \multirow{2}{*}{36} & Pre & 3.0278 & 1.50211 & \multirow{2}{*}{21.086} & \multirow{2}{*}{35} & \multirow{2}{*}{.001} & \multirow{2}{*}{0.92} \\
\hline & & Post & 11.4444 & 2.22254 & & & & \\
\hline \multirow{2}{*}{ Critical } & \multirow{2}{*}{36} & Pre & 2.0833 & 1.31747 & \multirow{2}{*}{13.863} & \multirow{2}{*}{35} & \multirow{2}{*}{.001} & \multirow{2}{*}{0.82} \\
\hline & & Post & 5.3889 & .72812 & & & & \\
\hline
\end{tabular}

Table (1) shows that "there was a statistically significant difference between the mean scores of the study sample in the EFL listening comprehension test in the pre-post assessment, in favor of the post assessment". 
Table (2) shows that the mean score of the study group in the post application of the EFL listening comprehension skills test was higher than their score in the EFL listening comprehension skills pre-test in the literal skills; $t$-value is (17.930), which is significant at the (0.001) level. The effect size here is high as $\square 2$ is higher than 0.14 . Thus, it can be said that podcasting positively affected literal listening comprehension skills among the study participants.

Findings also indicated that the mean score of the study group in the post application of the EFL listening comprehension skills test was higher than that in the EFL listening comprehension skills on the pre-test in the inferential skills; $t$-value is (21.086), which is significant at the (0.001) level. The effect size here is high as $\square 2$ is more than 0.14 . Again, it can be said that podcasting positively affected inferential listening comprehension skills among the study participants.

Furthermore, findings indicated that the mean scores of the study group in the post application of the EFL listening comprehension skills test were higher than that of the EFL listening comprehension skills in the critical level; t-value is (13.863), which is significant at the $(0.001)$ level. The effect size here is high as $\square 2$ is greater than 0.14 . Consequently, it can be said that the participants' critical skills has been developed as a result of using podcasting.

\section{Discussion and Interpretation of the Results}

Results of the study revealed that there was a statistically significant difference at 0.001 between the mean scores of the study group in the prepost test in favor of the post test. Hence, it was concluded that using podcasting was effective in developing EFL listening comprehension skills. This may be attributed to different reasons. Some of the prominent features of podcasts which made the teaching process vivid and enjoyable to students are: content choice, portability and rehearsal many times before recording audios, listening to their classmates' generated podcasts, adding comments to each other and 
evaluating each other. Moreover, podcasts provide unique repository of authentic oral language material, an aspect which has been neglected in favor of text based activities through students' books.

One of the noticeable advantages of podcasting that affect the students' listening comprehension is that it offered the researcher and students a wide range of possibilities for extra listening practice both inside and outside of the classroom. So, the participants could get authentic material at any time and any place to develop their listening comprehension skills. Moreover, podcasting is considered an opportunity to compensate for short time of sessions. So, the teacher could extend and duplicate the sessions outside the classroom.

Another remarkable advantage of podcasting is that it doesn't require much technical information or expensive equipment. All students already have technological devices computers, laptops, MP3 players, tablets and smart phones. This helped the researcher and students to contact each other whenever and wherever they want.

\section{Recommendations of the Study}

Based on the results of the present study, the following recommendations should be taken into consideration:

1- The English language teachers should use podcasts to aid students practice listening comprehension in a meaningful context.

2- Students should listen to English conversations, stories, series podcasts inside and outside the class to get an access to authentic languages.

3- Schools should be provided with access to the internet inside the classrooms. 


\section{Suggestions for Further Research}

The results drawn from this study pointed to a need to conduct further research as follows:

1- There is a need for investigating the effect of using podcasts for developing listening comprehension skills among other groups of learners: primary, preparatory and university.

2- This study used podcasts of stories as a listening material, The effect of a study using other kind of listening materials for podcasts is needed.

3- A study is needed for investigating how podcasts can effectively be implemented to support mobile learning and how this approach affects learning motivation and/ or other affective variables such as attitude and self-efficacy in an online environment.

4- Comparing teacher-generated to students-generated podcasts is an area suggested for research 


\section{Reference}

Abdel-Hafez, A. (2006). The effect of a suggested training program in some metacognitive language learning strategies on developing listening and reading comprehension of first year EFL students.

Unpublished M.A thesis, Faculty of Education, Minia University.

Abdel Khalk, W. (2011). The effectiveness of using role playing activities on developing some speaking skills for second prep school students. Unpublished M.A. thesis Institute of Educational Studies, Cairo University.

Abeddaim, S. (2013). The effectiveness of using podcasts for developing learners' listening skills. Case study: second year students at Omar Idriss El-Kantara secondary school. Published M. A. Thesis. Faculty of Letters and Languages, University Mohamed Kheider of BISKRA.

Adams, C. (2006). Geek's guide to teaching in the modern age. Instructor, 115(7), 48-51. Retrieved from: www.ebscohost.com

Al-Hariree, A. (2004). The effect of some metacognitive strategies on developing listening comprehension skills of secondary school students. Unpublished M. A. Thesis, Faculty of Education, Zagazig University.

Al Qasim, N. \& Al Fadda, H. (2013). From call to mall: The effectiveness of podcast on EFL higher education students' listening comprehension. Candian Center of Science and Education. (6)9. 30-41.

Ashraf, H., Noroozi, S., \& Salami, M. (2011). E-listening: The promotion of EFL listening skill via educational podcasts. Proceedings of the International Conference on e-Learning. Retrieved from http://ehis.ebscohost.com/ehost/ 
Bozorgian, H. \& Pillay. H. (2013). Enhancing foreign language learning through listening strategies delivered in L1: An Experimental Study. International Journal of Instruction. 3(7), pp 27-33. Retrieved from: www.e-iji.net.British Journal of Education.

Brown, H. (2000). Principles of language learning and teaching $\left(2^{\text {nd }} e d\right)$. San Francisco, California.

Buffington, M. (2008). What is Web 2.0 and how can it further Art education?. National Art Education Association. 61 (3), 36-41. Retrieved 28 July, 2017, from http://www.jstor.org/stable/27696295

Cabezas, E. D. (2015). The relationship between listening proficiency and speaking improvement in higher education: Considerations in assessing speaking and listening. Higher Learning Research Communications, 5(2), 34-56.

Cebeci, Z., \& Tekdal, M. (2006). Using Podcasts as audio learning objects. Interdisciplinary Journal of Knowledge and Learning Objects, 2, 47-57.

Duzer, C. (1997). Improving ESL learners' listening skills: At the workplace and beyond. Center for Applied Linguistics. Retrieved from http://www.cal.org.

El-koumy, A. (2002). Effects of skills-based versus whole language approach on the comprehension of EFL students with low and high listening ability levels. An Online ERIC Database Full Text. No.ED449670. 
Flowerdew, J. \& Miller, L. (2005): Second Language learning : Theory and practice, New York: Cambridge University Press.

Forbes, D. \& Khoo, E. (2015). Voice over distance: A case of podcasting for learning in online teacher education. Routledge, 36 (3). 335-350.

Fox, A. (2008). Using podcasts in the EFL classroom. The TESL-EJ, 11(4).

Goh, C. (2000). A cognitive perspective on language learners' listening comprehension problems. System 28, 55-75.

Grognet, A. \& Duzer, V. (2002). Listening skills in the workplace. Spring Institute for International Studies, ED 468604, pp. 1-5.

Gul Ince, H. (2015). EFL learners' perceptions of educational podcasting. Published M. A. thesis, Ihsan Dogramaci Bilkent University, Ankara.

Hamouda, A. (2013). An investigation of listening comprehension problems encountered by Saudi students in the EL listening classroom. International Journal of Academic Research in Progressive Education and Development, 2(2), 113-155.

Hasan, Md. M., \& Hoon, T. B. (2012). ESL learners' perception and attitudes towards the use of podcast in developing listening skills. The English Teacher, 41(2), 160-173.

Hassen, D. (2016). The influence of podcasts on EFL student's listening comprehension. Published M. A. Thesis, Faculty of Letters and Languages, University Mohamed Kheider of BISKRA.

Hemmati, F. Gholamrezapour, Z. \& Hessamy, G. (2015). The effect of teachers' storytelling and reading story aloud on the listening comprehension of Iranian EFL learners. Theory and Practice in Language Studies, 5 (7), pp. 1482-1488. 
Hew, K. F. (2009). Use of audio podcast in K-12 and higher education: A review of research topics and methodologies. Education Technology Research and Development, 57, 333357doi:10.1007/s11423-008-9108-3.

Kavaliauskienè, G. \& Anusienė, L. (2009). English for specific purpose: Podcasts for listening skills. Santalka. Filologija. Edukologija, 17(2): $28-37$

Liu, Y. (2009). The utilization of listening strategies in the development of listening comprehension among skilled and less-skilled nonnative English speakers at the college level. Published Ph. D. Dissertation, Texas A \& M University.

Lucking, R., Purcell, S., \& Christman, E. (2006). Can you podcast?. National Science Teachers Association.30 (1). Retrieved 28 July, 2017 from http://www.jstor.org/stable/43181886

O'Bannon, B., Lubke, J., Beard, J. \& Britt, V. (2011). Using podcasts to replace lecture: Effects on student achievement. Computers \& Education,57, 1885-1892. Retrieved from www.elsevier.com/locate/compedu

Radwan, S. (2010). Using dictogloss strategy for developing some EFL listening comprehension skills among secondary school students. Unpublished MA thesis, Faculty of Education, Benha University.

Rezaei, A., \& Hashim, F. (2013). Impact of awareness raising about listening micro-skills on the listening comprehension enhancement: An exploration of the listening micro-skills in EFL classes. Australian Journal of Teacher Education, 38(8), 1-15. 